\title{
Lone hunger striker spurs Nepal to action
}

\section{Country's system of political patronage in science exposed.}

\section{BY SMRITI MALLAPATY}

A hunger strike by a senior academic in Nepal has forced the government to backtrack on its system of political patronage in academia and highlighted the damage it has inflicted on medical services, education and research.

Govinda KC, a physician and professor at the Institute of Medicine (IOM), part of the leading Tribhuvan University (TU) in Kathmandu, began a protest fast on 8 February. His demands included the reinstatement of the medical institute's former dean, or the appointment of a new one; disciplinary action against staff involved in granting unregulated licences to private medical colleges; and the establishment of public medical colleges in rural areas. Dozens of his colleagues staged a walkout in solidarity, causing outpatient services at TU Teaching Hospital to grind to a halt.

KC's hunger strike was triggered by the resignation in December of the IOM dean, Prakash Sayami, following pressure on him to grant affiliations to private medical colleges. Such colleges must be formally affiliated to a university, and can become profitable businesses through student fees once this is achieved. Sayami had become concerned about the quality of education that they offered.

On 11 February, within hours of being sworn in, Prime Minister Sushil Koirala set a 24-hour ultimatum for TU to appoint a new dean. The university duly selected senior physician Rakesh Srivastav - a decision welcomed by $\mathrm{KC}$, but one that was not enough for him to call off his protest (he had ended previous hunger strikes after being promised reforms).

"I am fasting because I want to end the corruption in the education and health institutions," he said. "I am confident that my demands will be met." KC finally ended his fast on 15 February, after the government agreed to meet almost all of his demands.

Political appointments in academia are not unusual in Nepal. "Members of the leadership team in universities are selected by the ruling party or coalition," says Kedar Bhakta Mathema, a former vice-chancellor of TU. From executive level to department heads, "it is people who can push and pull the levers of political power that can get into these positions", Pitamber Sharma, a former TU professor, told Nature.

But by sidelining academic merit, the research culture in Nepal has suffered, academics say. Leading positions are given to individuals who are unable to bring in research funding, argues Kamal Krishna Joshi, another former TU vice-chancellor. With government funding and student fees providing the bulk of the universities' limited funds, researchers have had to rely on their own connections and efforts to bring in cash, he says.

Political meddling has also exacerbated an uncomfortable reality in the country. "Research was never taken seriously in academic institutions in the past, it is not taken seriously even now," says Sharma. "I am fasting Worst affected are because young scientists, many toend the of whom have left to corruption in study and work abroad. corruption in Most of the funding the education for the Nepal Agriculand health tural Research Council institutions." and the Nepal Academy of Science and Technology, both in Kathmandu, comes from the government and is spent on salaries. A 2010 survey by the academy found that $68 \%$ of participants claimed to have insufficient equipment for their research needs. Sharma adds that, from his own observations, Nepal is at a substandard level on many measures, including the quality of its journals and the number of publications in international journals.

But there are some positives. Last year saw spending on agricultural research - a crucial sector in Nepal - more than triple compared with 2009 , from 520 million to 1.75 billion Nepalese rupees (US $\$ 5.25$ million to $\$ 17.6$ million).

But how much KC's fast will change things remains to be seen. Hira Bahadur Maharjan, the current TU vice-chancellor, denies claims of party interference. "In a democracy, everyone carries a political ideology. Appointed officials just happen to have a certain ideology, which is not related to their appointment," he says. The government refused to comment on the issue.

\section{CORRECTION}

The News story 'Iconic island study on its last legs' (Nature 506, 140-141; 2014) wrongly gave the name of Michigan Technological University as Michigan Technical University. 